University of Nebraska - Lincoln

DigitalCommons@University of Nebraska - Lincoln

$6-5-2020$

\title{
Remote sensing and three-dimensional photogrammetric analysis of glaciofluvial sand and gravel deposits for aggregate resource assessment in McHenry County, Illinois, USA
}

\author{
Xiaodong Miao \\ Linyi University, miaoxiaodong@lyu.edu.cn \\ Christopher J. Stohr \\ University of Illinois at Urbana-Champaign \\ Paul R. Hanson \\ University of Nebraska-Lincoln, phanson2@unl.edu \\ Qiansuo Wang \\ Luoyang Normal University
}

Follow this and additional works at: https://digitalcommons.unl.edu/natrespapers

Part of the Mining Engineering Commons, Natural Resources and Conservation Commons, Natural Resources Management and Policy Commons, and the Other Environmental Sciences Commons

Miao, Xiaodong; Stohr, Christopher J.; Hanson, Paul R.; and Wang, Qiansuo, "Remote sensing and threedimensional photogrammetric analysis of glaciofluvial sand and gravel deposits for aggregate resource assessment in McHenry County, Illinois, USA" (2020). Papers in Natural Resources. 1267.

https://digitalcommons.unl.edu/natrespapers/1267

This Article is brought to you for free and open access by the Natural Resources, School of at DigitalCommons@University of Nebraska - Lincoln. It has been accepted for inclusion in Papers in Natural Resources by an authorized administrator of DigitalCommons@University of Nebraska - Lincoln. 


\title{
Remote sensing and three-dimensional photogrammetric analysis of glaciofluvial sand and gravel deposits for aggregate resource assessment in McHenry County, Illinois, USA
}

\author{
Xiaodong Miao, ${ }^{1}$ Christopher J. Stohr, ${ }^{2,3}$ \\ Paul R. Hanson, ${ }^{4} \&$ Qiansuo Wang ${ }^{5}$
}

1 Research Center of the Tibetan Environmental Change, Shandong Provincial Key Laboratory of Water and Soil Conservation and Environmental Protection, School of Resource and Environmental Sciences, Linyi University, Linyi 276000, PR China

2 Applied Geo-Imaging Solutions, Inc., Catlin, IL 61801, USA

3 Illinois State Geological Survey, University of Illinois at Urbana-Champaign, Champaign, IL 61820, USA

4 Conservation and Survey Division, School of Natural Resources, University of Nebraska-Lincoln, Lincoln, NE 68583, USA

5 School of Land and Tourism, Luoyang Normal University, Luoyang 471934, PR China

Corresponding author: X. Miao, Linyi University, Shandong Province, PR China; email miaoxiaodong@lyu.edu.cn

\begin{abstract}
Sand and gravel deposits, one of the most common natural resources, are used as aggregates mostly by the construction industry, and their extraction contributes significantly to a region's economy. Thus, it is critical to locate sand and gravel deposits, and evaluate their quantity and quality safely and quickly. However,
\end{abstract}

Published in Engineering Geology 274 (2020) 105695

doi:10.1016/j.enggeo.2020.105695

Copyright (C) 2020 Elsevier B.V. Used by permission.

Submitted 23 January 2020; revised 18 May 2020; accepted 20 May 2020; published 5 June 2020. 
information on aggregate resources is generally only available from conventional two-dimensional (2-D) geologic maps, and direct field measurements for quality analysis at outcrops are time consuming and are often not possible due to safety concerns, or simply because exposures are too difficult to access. In this study, we presented a methodology to locate and evaluate aggregate resources, including the traditional methods of field surveying and borehole investigation for the entire McHenry County, Illinois, USA and new three-dimensional (3-D) photogrammetric models and remote sensing technologies at an active gravel pit. Thus acquired data sets allowed us to obtain key information for successful aggregate resource management: spatial occurrence, thickness, texture, paleocurrents, lithology and land use compatibility. In addition, remote sensing and photogrammetric techniques allowed for very quick and safe assessment of fundamental properties like particle size, paleocurrent direction and sorting, especially in inaccessible and/or unsafe outcrops. In summary, this paper demonstrated how remote sensing and photogrammetric technology can improve the efficiency and safety in resource assessment strategies, and the methodology used in our study can be applied to the development of autonomous mining and resource asset management elsewhere.

Keywords: Sand and gravel resources, Pit Mining, Photogrammetry, Remote sensing, Safety, Illinois

\section{Introduction}

Sand and gravel deposits are vital aggregate resources that contribute significantly to the economy as essential components of the construction industry (Masters, 1978; Langer, 1988; Crimes et al., 1992; Merritt, 1992; Poulin et al., 1994; Sutphin et al., 2006; Bayer et al., 2011; Comunian et al., 2011). Demand of surface and near-source supplies of aggregate resources upsurges due to the rapid expansion of some urban and metropolitan areas. The high demand and elevated price is compounded by a simultaneous rise in transportation costs as aggregate haul distances have been gradually increasing as local sources of aggregate resources diminish (Langer, 1988, 2002; Drew et al., 2002; Habert et al., 2010; loannidou et al., 2017). Thus, locating and protecting natural aggregate sources are important for economic growth, environmental protection, and maintaining a high quality of life (Horvath, 2004).

With this background, it is critical to locate sand and gravel deposits, and evaluate their quantity and quality safely and quickly. However, aggregate resource quality and quantity are generally only available from conventional two dimensional (2-D) geologic maps. These 
maps usually illustrate where the aggregate resources are, but often fail to provide information regarding thickness, depth of burial and clast sizes. More importantly, direct field measurements for quality analysis at outcrops are very time consuming and are often not possible because of safety concerns, or simply that exposures are too vertically high to safely access.

In this study, we applied remote sensing technologies and new 3-D photogrammetric models to investigate and assess the sand and gravel resources at an active gravel pit in McHenry County, Illinois, USA. We also generated a geologic map based on shallow soil data and deep stratigraphic boreholes. These technologies not only enable the assessment of many important aspects related to aggregate resources, but also demonstrate how remote sensing technologies and new 3-D photogrammetric models can be used to fulfill the task safely and quickly.

\section{Methodology}

\subsection{Study site}

We selected McHenry County in northeastern Illinois as the study site, because historically significant quantities of sand and gravel were mined in this county (Figs. 1, 2), and demand is extremely high due to its close locality to the Chicago metropolitan area. Sand and gravel deposits have been extracted from McHenry County mainly from three geological deposits: outwash plains, valley trains, and icecontact stratified drift and outwash deposits (Anderson and Block, 1962; Willman and Frye, 1970; Curry et al., 1997). Pebble count data show that dolomite dominates the rock type by $80-90 \%$, and limestone, chert, shale, granite, quartzite, gneiss and other lithologies constitute the remainder (Anderson and Block, 1962). In the last two decades, surficial mapping and three-dimensional (3-D) mapping at a variety of scales (e.g., Carlock et al., 2016; Lau et al., 2016) have provided important new data on the glacial geology of the county. On the other hand, the thickness and burial depth of sand and gravel deposits, two important factors of economic interest to the aggregate industry, were not inventoried as part of the mapping. 

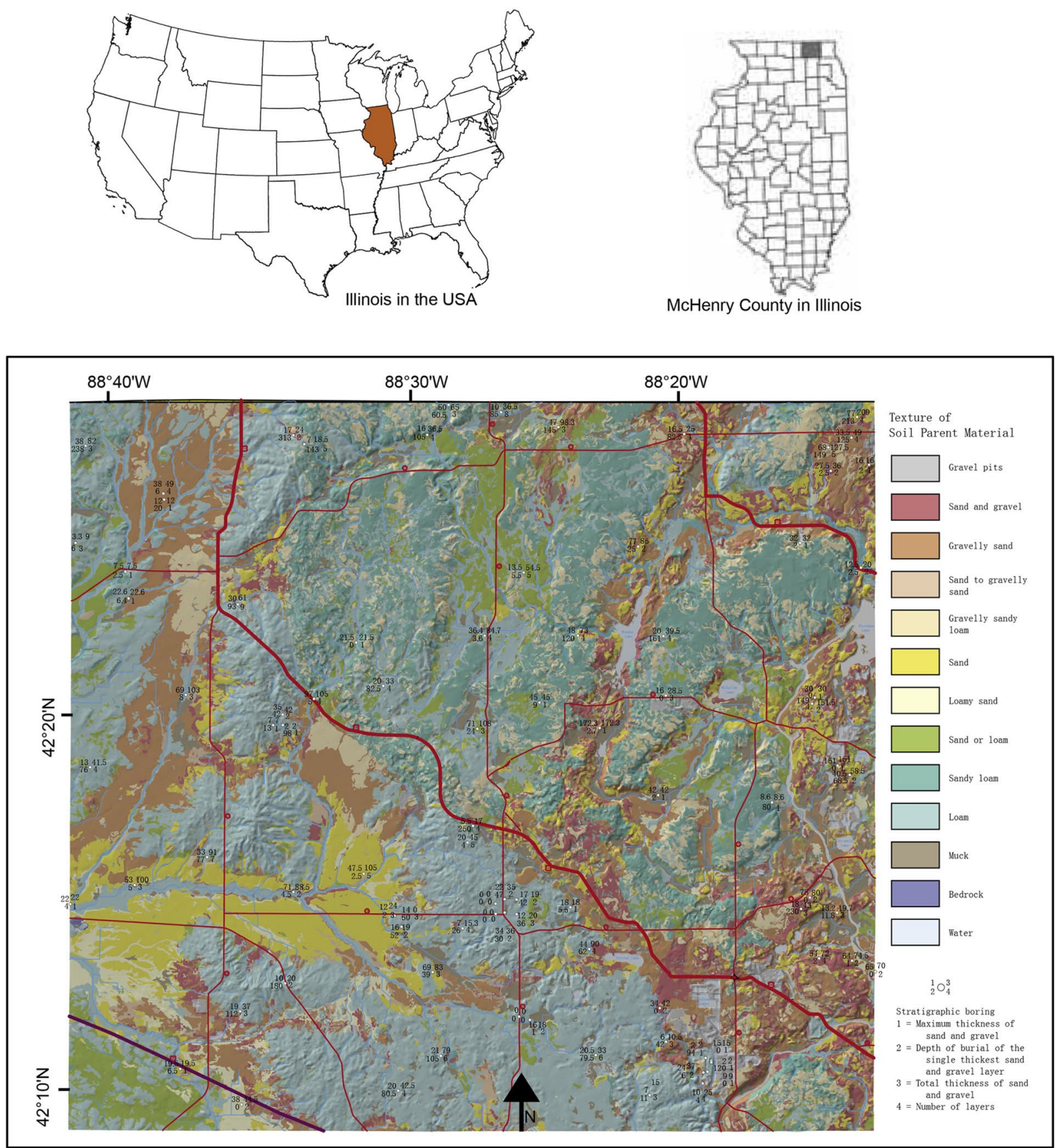

Fig. 1. Location of McHenry County, Illinois and sand and gravel resources (warm colors) based on textures from soil parent materials (SSURGO data). Also shown are geologic drilling sites and generalized core logs and major roads (red). See the more detailed version in the supplementary data for thickness and burial depth information. 


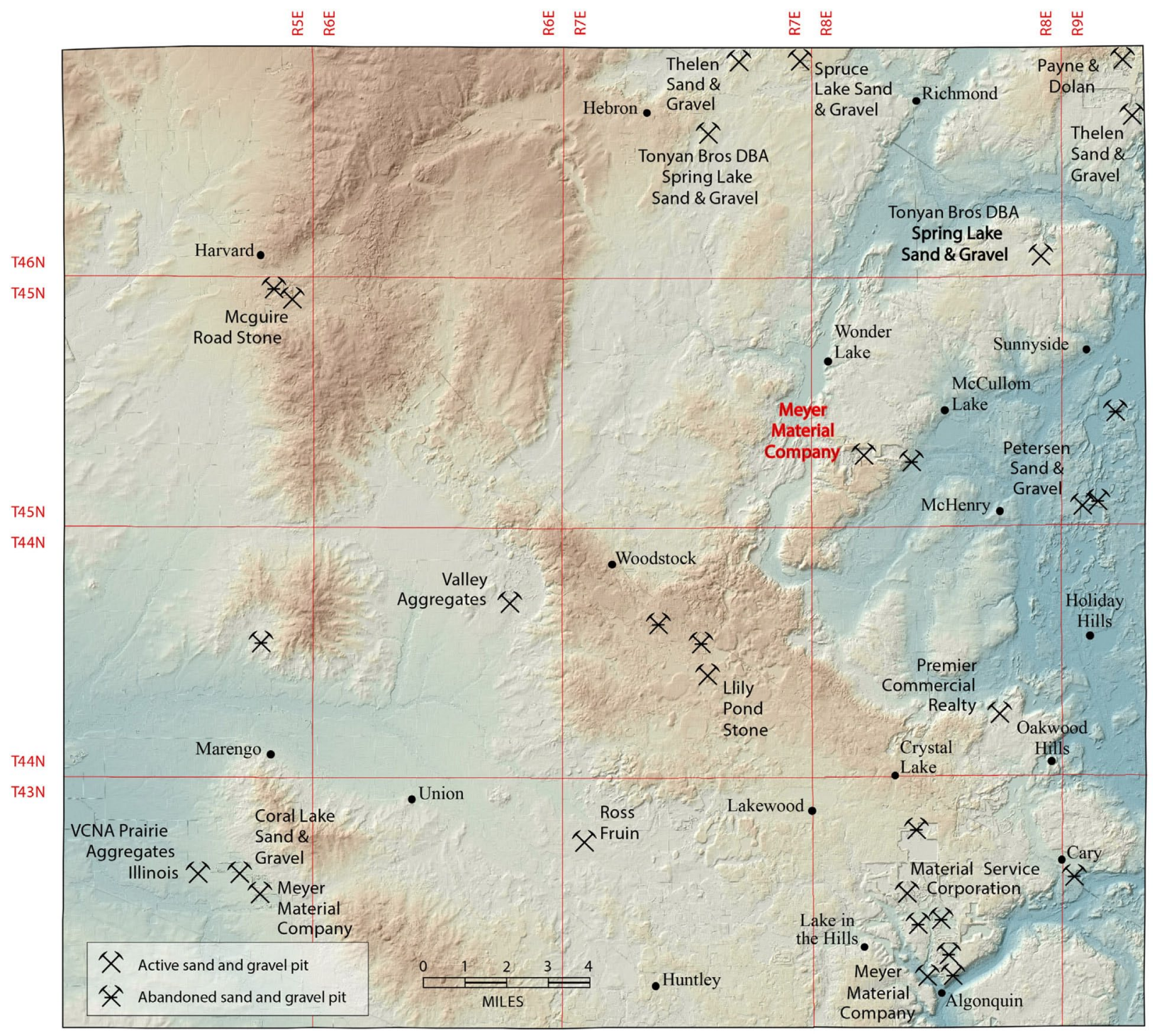

Fig. 2. Names and locations of active and abandoned sand and gravel pits in McHenry County, with the LiDAR-derived shaded relief image: tan colors indicate areas of higher elevation, and blue areas are lower elevation. Meyer Material Company (Figs. 3-5) is highlighted in red. Major towns are also shown.

\subsection{3-D photogrammetric models and remote sensing technologies}

In this study, orthophotography and 3-D models were developed using close range photogrammetry to make remote measurements to characterize sand and gravel deposits on high and unsafe outcrops 


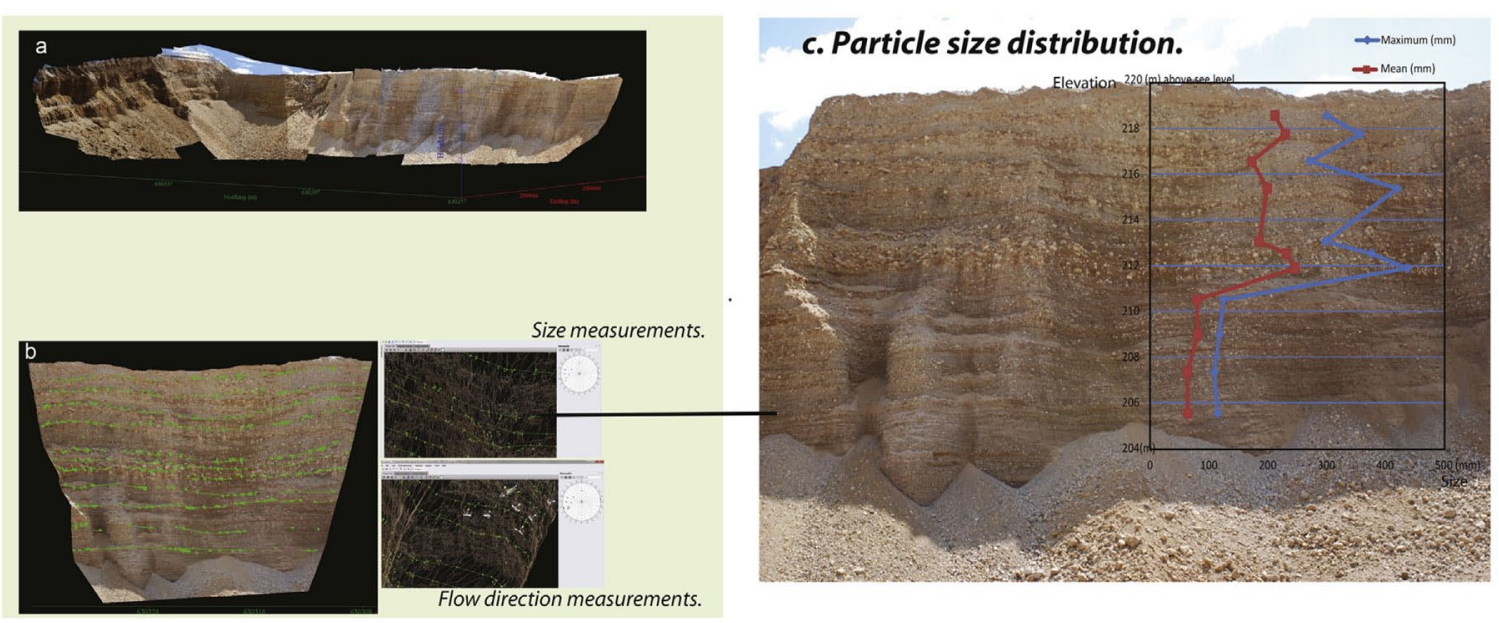

Fig. 3. Photogrammetry of the steep and active mining face of sand and gravel at the Meyer Material pit. (a). 2-D photos were converted to georeferenced 3-D image using the Sirovision program. The exposure is around $13 \mathrm{~m}$ high. (b). Screen shots of gravel size and flow direction measurements. Green indicates the line of paleocurrent and clast size measurements. (c). Maximum and mean size ( $\mathrm{mm}$ ) of the clasts measured from each depth.

of a 214-m long, 13-m high exposure at a pit owned by the Meyer Material Company (Figs. 2, 3) located 45 miles northwest of Chicago, Illinois.

The use of remote sensing techniques is not only a comparably faster alternative to directly measure geologic materials with inaccessible and unstable slopes, but many mines and pits prohibit study and direct measurements of active faces because of liability and reasonable concerns of safety (Haneberg, 2008; Stohr et al., 2015a, 2015b).

Remote (terrestrial) sensing technologies, including conventional digital camera photography, close-range photogrammetry, aerial and terrestrial LiDAR and image processing, were used to analyze and classify sediments exposed in an active gravel pit face for sedimentological and economic resource quantification. These methods have been used to study the distribution of bedrock, sediment types, gravel and other aggregate resources at other locales (Stohr et al., 2011, 2015a, 2015b). 2-D stereophotographs recorded with a Nikon D-6 camera were orthorectified to georeferenced 3-D images (Fig. 3a) using Sirovision ${ }^{\mathrm{TM}}$ software. Details for georeferencing and orthorectification of stereophotography using Sirovision ${ }^{\mathrm{TM}}$ are described in Stohr et al. (2011) including establishing new geodetic 
control using GNSS satellite surveying, reflectorless total station measurements of points on the pit face, and preparation of imagery for analysis. Correction of relief displacement and optical errors by stereoorthorectification process, terrestrial LiDAR, with georeferencing to state plane coordinates in the current datum, permit precise and accurate measurement of sedimentary characteristics on photographs with the capability of calculating distances and display on geographic information system and 3D software.

ERDAS Imagine ${ }^{\mathrm{TM}}$ image processing software was used to perform unsupervised classification of raw camera photography from the same Meyer Pit in McHenry, IL. Unsupervised classification creates statistically separable classes purely based on spectral information, with the results not as subjective as manual visual interpretation. The photograph was selected because the exposed strata were uniformly shaded, thereby reducing the unwanted complications of partial shadowing and dappled illumination.

As expected in our study the spectral classes appear to be related to sedimentary textures. The relationship permits automated distinction of highly desirable textures, gravel, from sand and finer sediments with no or minimal human interpretation is notable.

\subsection{Lithofacies classifications}

The spectrally classified images were further classified using a lithofacies code devised by (Kemmis et al., 1988; Stohr et al., 2011). A lithofacies code is particularly useful because the hierarchical letter code is useful for quickly discerning dominant and secondary particle size and sorting (grading). The lithostratigraphic descriptions in Table 1 were made using measurements and inspection of sediments by photogrammetry and remote sensing of photographs and compared with observation of sediments in stockpiles and on the pit floor. This is an improvement over gravel quantity estimates made with only a reflectorless total station and observations through the instrument telescope (Kemmis et al., 2006). Use of a lithofacies code for description is particularly desirable for mapping and comparing profiles and boring logs. The code used for this study consists of three basic parts: gross particle size, gross texture range and distribution, and bedding structures. 


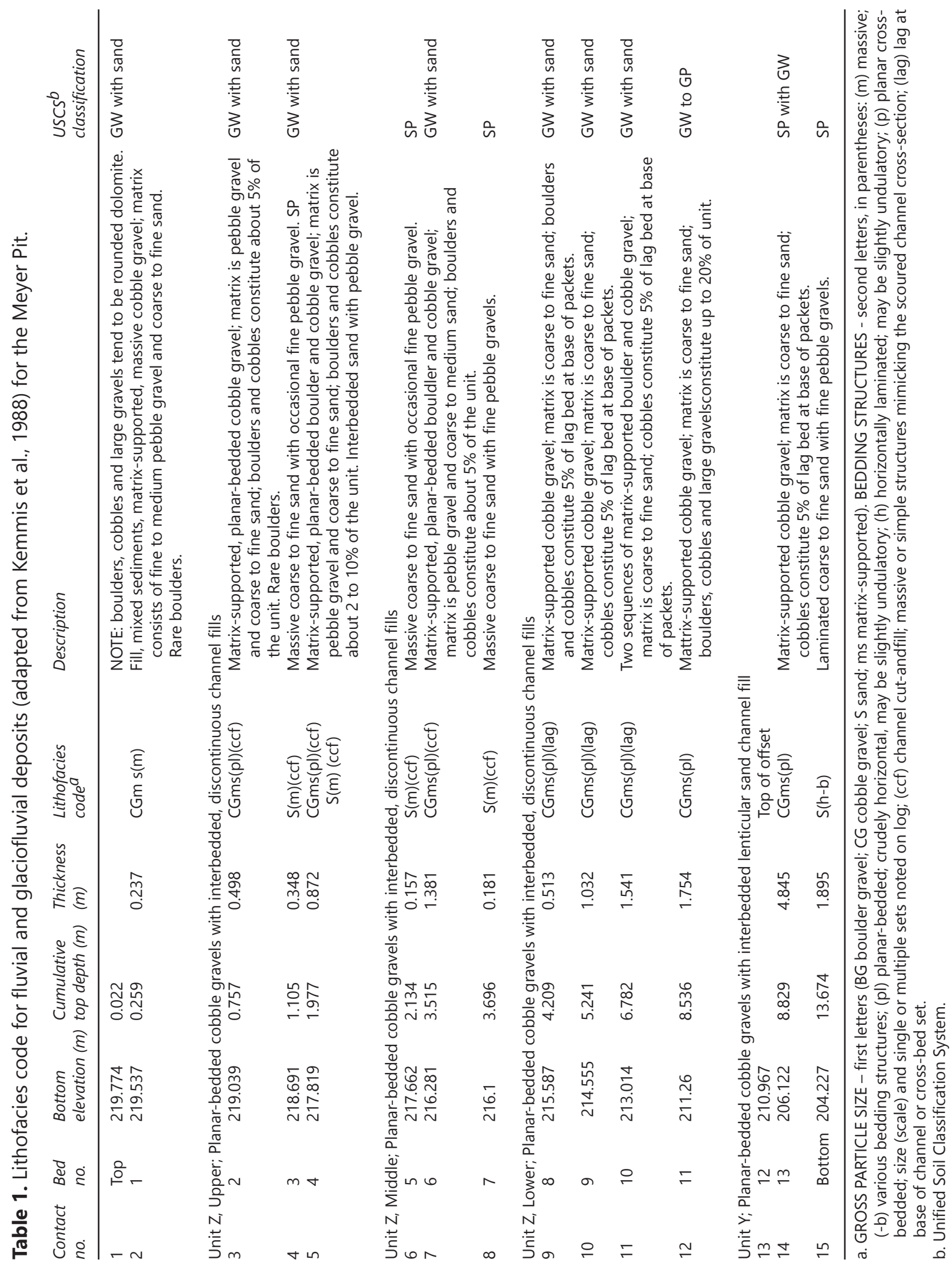


Bedding structures in the mine face were observed and classified. The lithofacies codes were expanded upon the code proposed by Miall (1978), Eyles et al. (1983) and Kemmis et al. (1988). The use of capital and lowercase letters and parenthetical classes was for notation ease in the field and later computer database sorting for numerical analyses, which may be the greatest benefit of the code.

The gross particle size classification indicates the predominant texture of the sediment. Coarse grained sediments are important indicators of the dominant fluvial processes that existed during deposition. Our classification includes minor constituents that were added for additional description. Whether a sediment is clast or matrix supported is an economic consideration for resource assessment and engineering consideration for excavation and processing.

\subsection{Spatial distribution, thickness and texture of sand and gravel}

We reclassified the mapped soil units and re-symbolized them based on grain size using the USDA-NRCS Soil Survey Geographic (SSURGO) database for McHenry County, Illinois. The soil survey provides spatial coverage and texture information of surface soils to depths of $150 \mathrm{~cm}$ that are generated primarily for agronomic purposes. Soil map units are nominally derived from the soil's parent material which distinguish different geologic rock types or glacial sediments. In Fig. 1, "warm" colors such as red, tan, and yellow represent relatively coarse-grained materials such as gravel, sand and gravel, and sand, respectively. Alternatively, units symbolized with "cool" colors such as blue and green represent relatively fine-grained materials such as silty clay and silt or clay loam, respectively, indicating little or no sand and gravel resources are present near the ground surface. In addition to the soil-parent-material derived data, we used borehole data and water well records to prepare a resource map to show the thickness, burial depth, and distribution of sand and gravel in McHenry County (Fig. S1 in Supplementary material).

Because of the importance of the texture of sand and gravel, a fully georeferenced, 3-D imagery model was used for making precise size measurements of cobble-sized clasts of a pit face at the Meyer pit. Clasts were measured across similar horizontal expanses (Fig. 3b) at 11 different depths. 10 to 26 clasts were measured at each depth, with 
the total measurements of 173 clasts. For each depth, we calculated the mean and reported its maximum size in Fig. $3 c$.

\subsection{Paleocurrents}

Gravel imbrication is a traditional tool for paleocurrent analysis (Miao et al., 2008, 2010), and Potter and Pettijohn (1977) formalized the tools of paleocurrent analysis. Pebble and cobble imbrication can be readily used to determine paleocurrent direction. In theory, the dip direction of the long-intermediate $(a b)$ plane of the pebbles point upstream, because flat clasts are in their most hydrodynamically stable position if they lean downstream. The strike, dip, and pitch of gravels in the exposure walls of gravel pits can be recorded, however, this assessment at many outcrops is dangerous as they are often either too high or not sufficiently stable to access.

In this study, instead of direct measurement of dip directions on the dangerous exposure walls of gravel pits which were actively being mined, we recorded dip direction on the computer after the 2-D image was georeferenced (the same as the size measurement) to a 3-D stereomodel using Sirovision software (Fig. 3b). The orthorectification of stereophotography recorded by uncalibrated cameras was developed and demonstrated by Karara and Abdel-Aziz (1974). 66 clasts were measured, covering the large exposure at the active mining surface of the Meyer pit (Fig. 3b). Finally, paleocurrent measurements from the $a b$ plane were plotted as rose diagrams using $30^{\circ}$ sectors.

\subsection{Gravel lithology and size}

Lithology affects the quality of the aggregate primarily based on how gravels weather, as highly weathered materials are not suitable for aggregate (Bahrami et al., 2015). To save time and increase efficiency, lithology can be determined on outcrops by classifying clasts shown by image processing of photography and photogrammetry (Carrea et al., 2016).

In this study, image processing of conventional RGB digital photographs was used to discriminate dolostone cobbles and boulders from smaller textures of mixed lithologies which is important for selecting mining equipment, material identification and sorting for con-

crete aggregate, and safety in mining operations. An unsupervised 
classification of 25 spectrally separable lithologic classes was made using the conventional isodata technique (Swain and Davis, 1978; Campbell and Wynne, 2011; Lillesand et al., 2015) to distinguish units containing desirable coarser sediments from less desirable finer sediments. Dolostone, especially weathered cobbles, may be classified as a deleterious aggregate depending upon composition.

\section{Results and discussion}

\subsection{Spatial occurrence, thickness and overburden of sand and gravel}

The resultant maps (Fig. 1 and Fig. 1 in Supplementary material), derived from the soil parent material data, can be interpreted as a guide for the availability of near-surface industrial mineral resources for McHenry County. The warm colors illustrate where sand and gravel can be found, and cool colors suggest that sand and gravel resources are not found near the ground surface.

In addition to mapping materials at the ground surface, we presented the deeper data by using borehole and water well records. The deeper stratigraphic subsurface information regarding sand and gravel resource has been recorded and extracted, including maximum thickness of a single layer, depth of burial, total thickness and number of layers of sand and gravel (Fig. S1). Thickness and depth of burial are very critical for sand and gravel resource evaluation. For example, a simple ratio (thickness to depth of burial) can be used, as a rule of thumb guide, to determine whether a particular site is economically profitable or not for end users in the mining industry. A thick sand and gravel layer with that underlies a thin overburden is ideal for resource extraction. Furthermore, Fig. 2 shows the active sand and gravel producers in McHenry County (Miao et al., 2016), overlain on the LiDAR topography (Domier and Luman, 2014).

\subsection{Texture of sand and gravel}

Aggregate texture is a fundamental for the aggregate industry, and here we use three methods to present this important information. First, Fig. 1 shows a plan view map that includes not only where sand 
and gravel resources can be found, but also the different size ranges, such as gravelly sandy loam and sand, through the use of different colors for McHenry County. Second, lithostratigraphic descriptions for individual gravel pits as shown in Table 1 also provide the size information. A measured section at the Meyer Pit showed $7 \mathrm{~m}$ of matrixsupported gravel consisting of about $5 \%$ cobbles or boulders at the top of the exposure, and $6 \mathrm{~m}$ of coarse to fine sand with pebble gravels at the bottom. Third, textural data collected using photogrammetry from pit faces can be used to indicate the quality and quantity of aggregate resources. Plots of both maximum and mean grain size (in $\mathrm{mm}$ ) on a photograph taken from the Meyer Pit provide a convenient visual format of textual data, after size measurements via the Sirovision program (Fig. 3C). Here, the largest boulder sizes range up to 642 $\mathrm{mm}$ in the upper $7 \mathrm{~m}$ of the exposure, while the largest clast is only $125 \mathrm{~mm}$ diameter in the lower $6 \mathrm{~m}$. These size data are hard to assess in a timely manner without using 3-D photogrammetric models.

Because clast size is an important property to consider when assessing aggregate quality (Laxton, 1992), Cobb and Fraser (1981) developed a sedimentological model to predict the texture of the sand and gravel deposits in Kane and McHenry Counties in northeastern IIlinois. Based on results from surface and sub-surface mapping of outwash deposits, along with field descriptions of exposures and sections, particle size analysis results suggest that the heterogeneous mixture of materials follow a trend based on distance from the glacial margin at the time of deposition. Deposits distal from the glacial source have decreased mean and maximum grain size, but increased sorting and higher sand-to-gravel ratios (Cobb and Fraser, 1981). This is important because demand for gravel, which is used for foundation support, drainage, concrete, and also for construction backfill, is greater than sand, and is a more desirable type of material for extraction as it has a greater economic value.

Aside from texture being an indicator of water's carrying capacity during transport and burial (Gomez, 2006; Miao et al., 2008), texture is important for aggregate resources in two ways. First, in general larger gravel sizes have greater economic value i.e., they are more expensive. Second, the size and shape of sand and gravel make a difference in the applications that they can be used for. For example, rounded gravel is used for perimeter drainage applications, while sand is used 


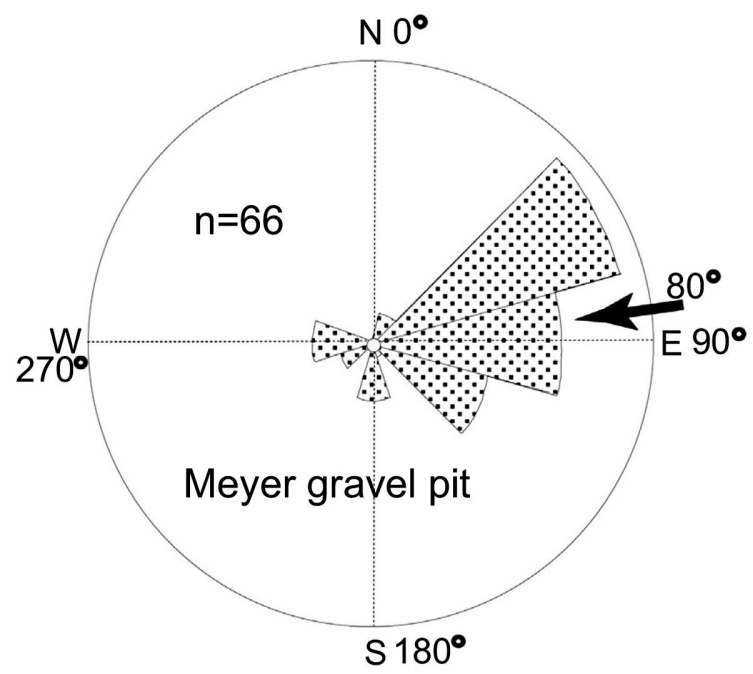

Fig. 4. Paleocurrent flow direction reconstructed from 66 measurements of imbricated clasts from an exposed face at the Meyer Pit. Arrow is the calculated vector mean, and data were determined from a stereophotography model.

for backfilling, foundation support for poured concrete and paving bricks, and as a major component of masonry products, such as mortar and stucco. Sand is also used for landscaping, golf courses, and recreational play areas.

\subsection{Paleocurrents of gravels}

The results from the Meyer Pit show that the sand and gravel sediments were deposited incrementally by periodic flooding that emanated from the east and northeast (Fig. 4). Directions of the vector mean $\left(80^{\circ}\right.$, East) was calculated by the method of Potter and Pettijohn (1977). This is consistent with the regional understanding that the glaciers of the Laurentide Ice Sheet came from the northeast, and the glacier-melting flood which deposited these sand and gravels as outwash emanated from the east (Anderson and Block, 1962; Masters, 1978).

The paleocurrent reconstruction, derived from the georeferenced 3D stereomodel (Fig. 3b), is important for assessing sand and gravel resources in McHenry County for two reasons. First, if a pit is mined out, a known paleocurrent can give a better prediction on which direction to either continue to mine, to seek expansion, or to develop new mines. Second, paleocurrents can be helpful for estimating 
aggregate texture trends because size tends to decrease from upstream to downstream due to reduction in carrying capacity in the downstream direction.

Although we think the uncertainty from georeferenced 3-D stereomodel-based clast size is very low, the uncertainty for paleocurrent measurement is higher due to the fact that we cannot fully reconstruct the $a b$ plane from the georeferenced photo. Nevertheless, photogrammetry makes it possible to make measurements on active pit faces, which are typically high and unstable as are those at the Meyer Pit. In addition, we emphasize that photogrammetry-based measurements on clast sizes and paleocurrents were collected much faster than traditional field measurements: it took us only a couple of hours to finish both size and paleocurrent analyses using the computer. Thus, the 3-D stereomodel can be applied in other locations for aggregate resource investigation.

\subsection{Image classifications on texture and lithology}

Classification of glaciofluvial sediments using a lithofacies code enables reliable searches for desired textures and the evaluation of processing the data without tedious manual comparison of unstandardized geologic descriptions. The results from an unsupervised classification show that differences in shadowing and moisture (dryness) interfered with spectral classifications (Fig. 5b), but demonstrated that some areas could be extracted and were deemed suitable for analysis (Fig. 5c).The narrow area of interest on the left is a predominantly dry exposure (Fig. 5d), whereas the larger area to the right (Fig. 5e) is partly moist. The entire exposure shows pronounced drying of the upper surface with moisture retained according to the grading, size and range in texture of the sediments or packing density. These characteristics can be used to infer quantitative textural information. Both areas of interest were extracted for unsupervised classification. The dry exposure shows that spectral classification of imagery is difficult to segregate into classes related solely by texture. A combination of dryness and apparent raveling and sloughing of materials from higher in the profile tends to cover the sediments which can obscure stratigraphic and textural data information.

Fig. 5 e shows the cropped section where natural moisture is retained, classified into four groups, including one group (composed of 

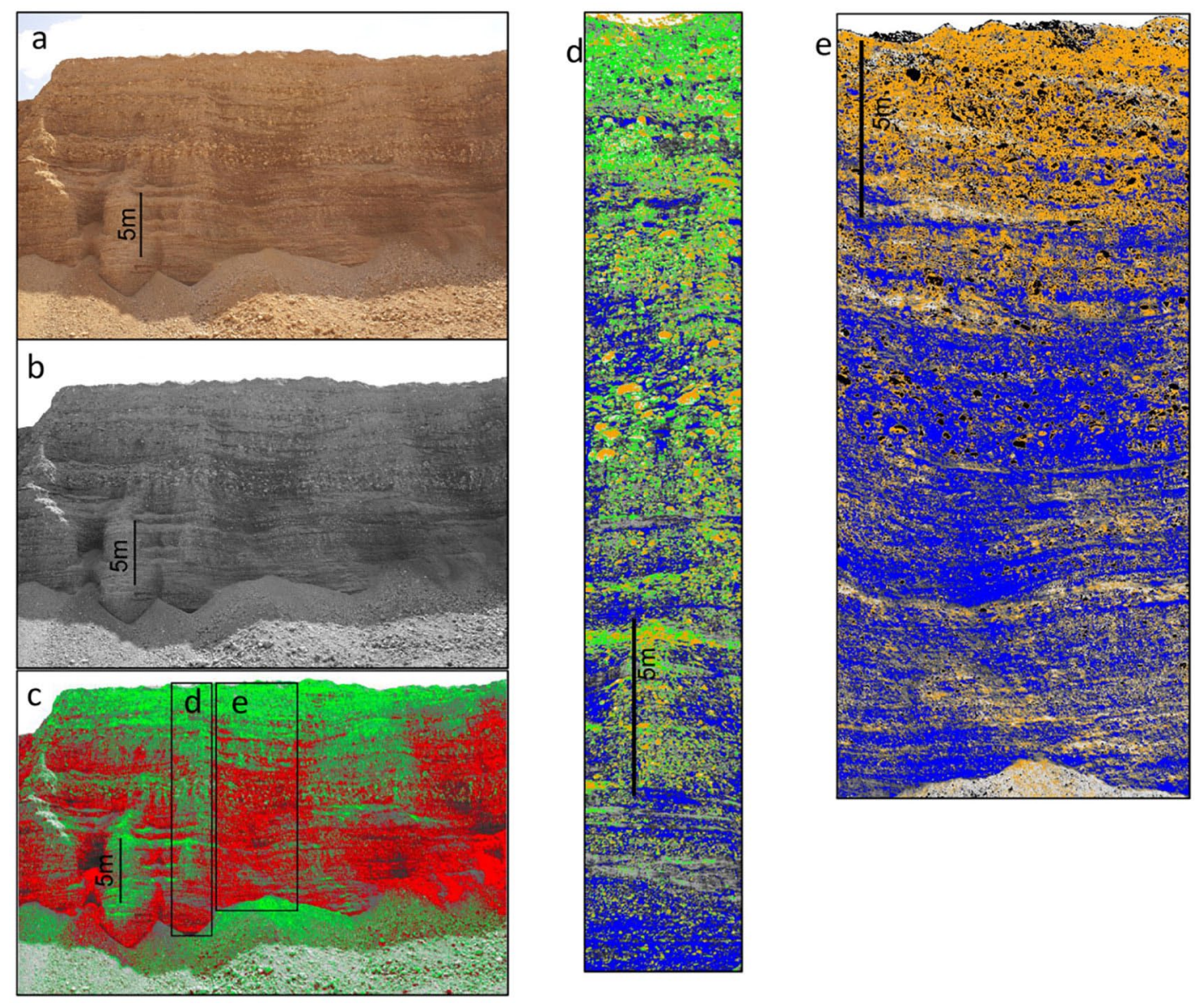

Fig. 5. Unsupervised image classification of a profile at the Meyer pit. (a). Original photo at the Meyer pit, unenhanced. (b). Profile photo classified into $25 \mathrm{spec}-$ trally separable classes (grayscale). (c). 25-class unsupervised classification reduced to 3 classes, light (green), dark (red) and unclassified (white, black). The classes seem to be related to sediment colour, texture and wetness. Coarse, drier, relatively well sorted, sediments (green), contrast with finer, moist, poorly sorted sediments (red). Two areas of interest (5d) are delineated for further analysis. (d): Dry section 25-classes grouped into 4 spectrally separable classes, green (dry, well-drained, coarse sediments), blue (poorly sorted and -draining, moist sediments), orange (cobbles or unclassified sediments). (e): Moist section 25-classes grouped into 4 classes, orange (dry, well-drained, coarse sediments), blue (poorly sorted and -draining, moist sediments), gray (intermediate or unclassified sediments). Black class in $\mathbf{d}$ and $\mathbf{e}$ includes limestone cobbles.

2 classes) that relates to limestone cobbles and boulders. The group does not precisely include the large fragments, but it is sufficient to approximate the volume of cobbles and boulders within the photo to be $9 \%$ of the total area. These large limestone cobbles and boulders are desired for aggregate resources. 


\subsection{Land use compatibility}

Not all of the sand and gravel deposits shown in Fig. 1 are available for mining because of land use conflicts, although they may meet specifications for construction aggregate. This is especially the case where mineable sand and gravel resources underlie residential and other developed areas. Using the current land use map produced by the Regional Planning Commission, McHenry County Department of Planning and Development, we classified the two areas where sand and gravel resources: (a) do not conflict with current land use practices and would theoretically be available for future extraction, and (b) cannot be mined due to current land use practices (Fig. 6). A significant amount of mineable resources are sequestrated due to land use, especially in the heavily urbanized eastern half of the County. Coincidentally, these areas are also near urban centers, the places where aggregate resources are most needed. On the other hand, these lost mineral resources may be viewed as future resources if zoning codes were to change in the future.

\subsection{Application to autonomous mining, resource evaluation and management}

Mining is inherently a hazardous and risky enterprise, increasingly relying upon automation with resource measurements to leverage capital, reduce costs and risks, and track progress in excavation and stockpile inventories for asset management - even remotely. Computer visualization of mine faces for autonomous excavation using a combination of remote sensing and lithofacies classification similar to those used in this investigation can improve efficiency at every stage of mining.

\section{Conclusions}

We presented the comprehensive assessment of sand and gravel resources at the county scale, including their spatial occurrence, thickness, depth of burial, size, flow direction and lithology. We further show that a significant amount of mineable resources are sequestrated 


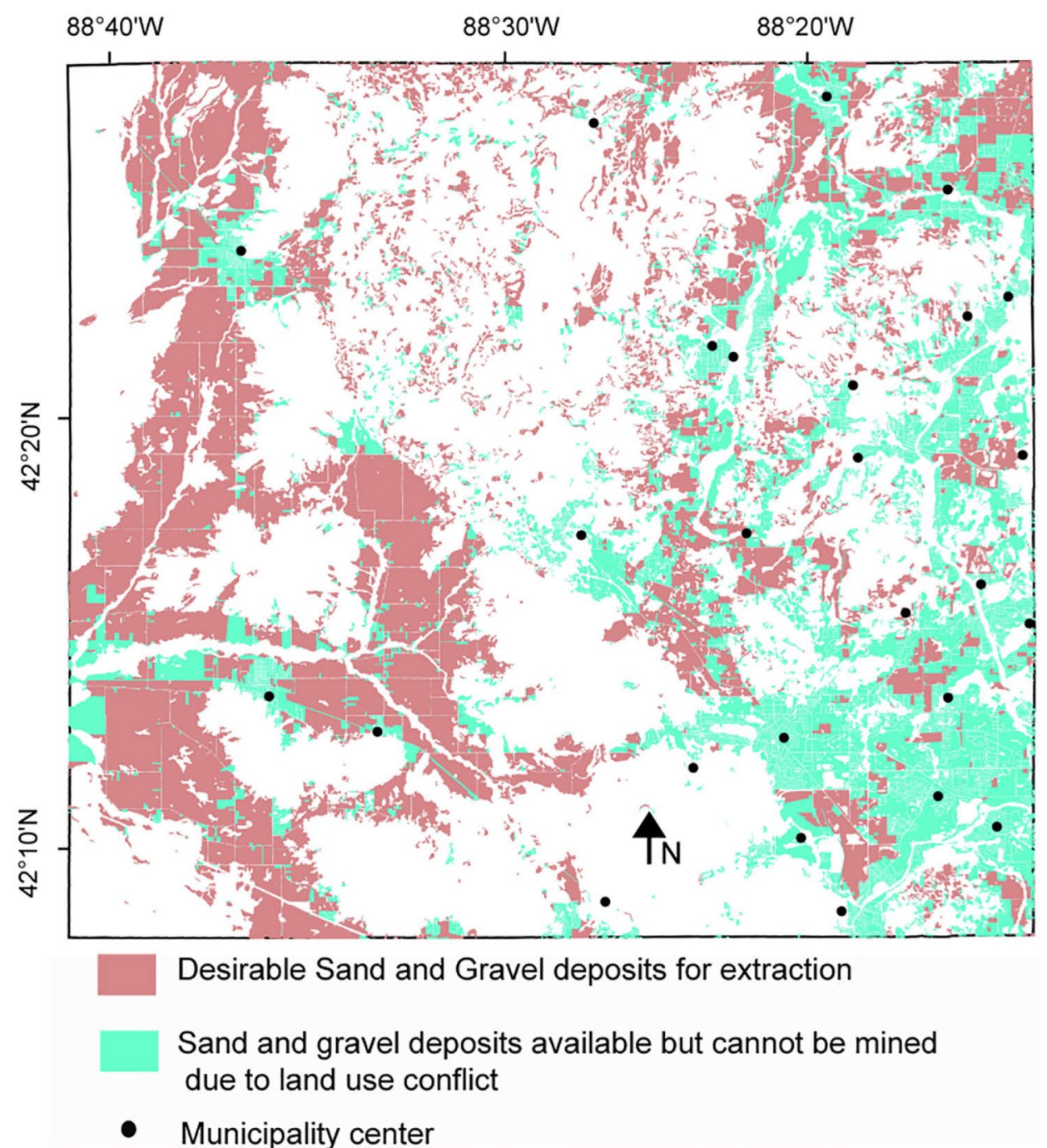

Fig. 6. Sand and gravel resources with the consideration of land use: green areas are where they are available but not accessible given the current land use. Red areas are where they can potentially be extracted; white areas represent no sand and gravel. Significant resources are sequestrated, especially near the municipality centers where the aggregate is needed the most.

due to land use conflicts, especially in the heavily urbanized eastern half of the McHenry County.

In addition, we demonstrated how photogrammetry and remote sensing technologies can help locate and evaluate key aspects of aggregate resources safely and quickly. Mining is inherently hazardous and the assessment of the quantity and quality of aggregate resources in the field is typically difficult given that pit faces are often high and 
unstable. The stereophotography and close-range photogrammetry methods used in this study allowed for remote measurements and characterizations of sand and gravel deposits on high and unsafe outcrops. The comprehensive methodology used in our study can be applied to the development of autonomous mining and resource asset management elsewhere in the future.

Supplementary data (Fig. S1) follows the References.

Competing Interest The authors declare that they have no known competing financial interests or personal relationships that could have appeared to influence the work reported in this paper.

Acknowledgments We thank Jane Domier, Jason Thomason and Steve Brown for cartographic assistance and discussion, McHenry County Regional Planning Commission for providing land use data, and Meyer Material Company for permission to investigate their sand and gravel pits, 2 anonymous reviewers for their constructive suggestions to improve the paper. This research was funded by Illinois State Geological Survey, University of Illinois at Urbana-Champaign and Linyi University LYDX2018BS058.

\section{References}

Anderson, R.C., Block, D.A., 1962. Sand and Gravel Resources of McHenry County. 336. Illinois State Geological Survey Circular, Illinois, pp. 1-15.

Bahrami, S., Aghda, S.M., Bahrami, K., Motamedi Rad, M., Poorhashemi, S., 2015. Effects of weathering and lithology on the quality of aggregates in the alluvial fans of Northeast Rivand, Sabzevar, Iran. Geomorphology 241, 19-30.

Bayer, P., Huggenberger, P., Renard, P., Comunian, A., 2011. Three-dimensional high resolution fluvio-glacial aquifer analog: part 1: field study. J. Hydrol. 405, $1-9$.

Campbell, J.B., Wynne, R.H., 2011. Introduction to Remote Sensing, Fifth edition. Guilford Press, pp. 667.

Carlock, D.C., Thomason, J.F., Malone, D.H., Peterson, E.W., 2016. Stratigraphy and Extent of the Pearl-Ashmore Aquifer, McHenry County, IL, USA. World J. Environ. Eng. 4, 6-18.

Carrea, D., Abellan, A., Humair, F., Matasci, B., Derron, M., Jaboyedoff, M., 2016. Correction of terrestrial LiDAR intensity channel using Oren-Nayar reflectance model: an application to lithological differentiation. ISPRS J. Photogramm. Remote Sens. 113, 17-29.

Cobb, J.C., Fraser, G.S., 1981. Application of sedimentology to development of sand and gravel resources in McHenry and Kane counties, northeastern Illinois. Trans. Am. Ophthalmol. Soc. 32, 64-95. 
Comunian, A., Straubhaar, J., Bayer, P., Renard, P., 2011. Three-dimensional high resolution fluvio-glacial aquifer analog: part 2: geostatistical modelling. J. Hydrol. 405, 10-23.

Crimes, T.P., Chester, D.K., Thomas, G.S.P., 1992. Exploration of sand and gravel resources by geomorphological analysis in the glacial sediments of the Eastern Lleyn Peninsula, Gwynedd, North Wales. Eng. Geol. 32 (3), 137-156. https://doi. org/10.1016/0013-7952(92)90042-w

Curry, B.B., Berg, R.C., Vaiden, R.C., 1997. Geologic Mapping for Environmental Planning, McHenry County, IL. 559. Illinois State Geological Survey Circular, pp. $1-79$.

Domier, J.E.J., Luman, D.E., 2014. LiDAR Surface Topography of McHenry County. Illinois County Geologic Map, ICGM McHenry-ST, Illinois.

Drew, L.J., Langer, W.H., Sachs, J.S., 2002. Environmentalism and natural aggregate mining. Nat. Resour. Res. 11, 19-28.

Eyles, N., Eyles, C.H., Miall, A.D., 1983. Lithofacies types and vertical profile models: an alternative approach to the description and environmental interpretation of glacial diamict and diamictite sequences. Sedimentology 30, 393-410.

Gomez, B., 2006. The potential rate of bed-load transport. Proc. Natl. Acad. Sci. U. S. A. 103, 17170-17173.

Habert, G., Bouzidi, Y., Chen, C., Jullien, A., 2010. Development of a depletion indicator for natural resources used in concrete. Resour. Conserv. Recycl. 54, 364-376.

Haneberg, W.C., 2008. Using close range terrestrial digital photogrammetry for 3-D rock slope modeling and discontinuity mapping in the United States. Bull. Eng. Geol. Environ. 67, 457-469.

Horvath, A., 2004. Construction materials and the environment. Annu. Rev. Energy Environ. 29, 181-204.

Ioannidou, D., Meylan, G., Sonnemann, G., Habert, G., 2017. Is gravel becoming scarce? Evaluating the local criticality of construction aggregates. Resour. Conserv. Recycl. 126, 25-33.

Karara, H.M., Abdel-Aziz, Y.I., 1974. Accuracy aspects of non-metric imageries. Photogramm. Eng. 40, 1107-1117.

Kemmis, T.J., Quade, D., Bettis, A., 1988. Hallet gravel pits, in natural history of Ledges State Park and the Des Moines Valley in Boone County. Geol. Soc. Iowa Guidebook 48, 37-71.

Kemmis, T.J., Hajic, E., Stohr, C., Stumpf, A., Nelson, S., Dexter, J., 2006. Stop 1-7 Midwest Materials Company Site, Lacon; Late Wisconsin Episode High Terrace Succession, Quaternary Deposits and History of the Ancient Mississippi River Valley, North-Central Illinois. In: Illinois State Geological Survey Open File Series 2005-7. 51st Midwest Friends of the Pleistocene Field Trip, an ISGS Centennial Field Trip, May 13-15 2005. pp. 1-101.

Langer, W.H., 1988. Natural aggregates of the conterminous United States. U.S. Geol. Surv. Bull. 1594, 1-33. 
Langer, W.H., 2002. Managing and Protecting Aggregate Resources. U.S. Geological Survey Open-file Report. pp. 02-415.

Lau, J., Thomason, J.F., Malone, D.H., Peterson, E.W., 2016. Modeling the sediment fill of the pre-glacial Troy Bedrock Valley, McHenry County, IL, USA. J. Geosci. Environ. Protect. 4, 107-122.

Laxton, J.L., 1992. A particle-size classification of sand and gravel deposits as a basis for end-use assessment. Eng. Geol. 32 (1-2), 29-37. https://doi. org/10.1016/0013-7952(92)90015-q

Lillesand, T., Kiefer, R.W., Chipman, J., 2015. Remote Sensing and Image Interpretation, 7th edition. Wiley \& Co, pp. 1-736.

Masters, J.M., 1978. Sand and Gravel and Peat Resources in Northeastern Illinois. Illinois State Geological Survey Circular. 503. pp. 1-11.

Merritt, J.W., 1992. A critical review of methods used in the appraisal of onshore sand and gravel resources in Britain. Eng. Geol. 32, 1-9.

Miall, A.D., 1978. Lithofacies types and vertical profile models in braided river deposits: a summary. Can. Soc. Petrol. Geol. Mem. 5, 597-604.

Miao, X., Lu, H.Y., Li, Z., Cao, G.C., 2008. Paleocurrent and fabric analyses of the imbricated fluvial gravel deposits in Huangshui Valley, the northeastern Tibetan Plateau, China. Geomorphology 99, 433-442.

Miao, X., Lindsey, D.A., Lai, Z., Liu, X., 2010. Contingency table analysis of pebble lithology and roundness: a case study of Huangshui River, China and comparison to rivers in the Rocky Mountains, USA. Sediment. Geol. 224, 49-53.

Miao, X., Lasemi, Z., Mikulic, D.G., Falter, M., 2016. Directory of Illinois Mineral Producers and Maps of Extraction Sites. Illinois State Geol. Surv. Circ. 584, 1-49.

Potter, P.E., Pettijohn, F.J., 1977. Paleocurrents and Basin Analysis. Springer-Verlag, New York, pp. 1-425.

Poulin, R., Pakalnis, R.C., Sinding, K., 1994. Aggregate resources: production and environmental constraints. Environ. Geol. 23, 221-227.

Stohr, C.J., Petrtas, J., Mikulic, D.G., Thomason, J., 2011. Stereophotographic measurement of joint and bedding orientation at Thornton Quarry, Illinois. Illinois State Geol. Surv. Circ. 579, 1-23. http://library.isgs.uiuc.edu/Pubs/pdfs/ circulars/c579.pdf

Stohr, C.J., Kemmis, T.J., Stumpf, J.J., Keefer, D.A., Stumpf, A.J., Stiff, B.J., Mikulic, D.G., 2015a. Measuring and describing outcrops that you can't actually touch. In: Lasemi, Z. (Ed.), Proceedings of the 47th Forum on the Geology of Industrial Minerals: Illinois State Geological Survey Circular. 587. pp. 13-20. http://library. isgs.illinois.edu/Pubs/pdfs/circulars/c587.pdf

Stohr, C.J., Stumpf, A.J., Stiff, B.J., 2015b. Collection and application of outcrop mea- surements in glacial materials for geo-engineering and hydrogeology along the Vermilion River, Central Illinois. Environ. Eng. Geol. 21, 63-74.

Sutphin, D.M., Drew, L.J., Fowler, B.K., 2006. Estimated sand and gravel resources of the South Merrimack, Hillsborough County, New Hampshire, 7.5-Minute Quadrangle. Nat. Resour. Res. 15, 183-203. https://doi.org/10.1007/ s11053-006-9021-6 
Swain, P.H., Davis, S.M., 1978. Remote Sensing: The Quantitative Approach.

McGraw-Hill International Book Company, pp. 1-396.

Willman, H.B., Frye, J.C., 1970. Pleistocene Stratigraphy of Illinois. 94. Illinois State Geological Survey Bulletin, pp. 1

\section{Supplmentary Data}

Fig. S1. Stratigraphic drilling sites within the county are shown on the map and labeled with 4 numbers that correspond to: 1. maximum thickness of one single layer (upper left) and 2. depth of burial of the single thickest sand and gravel layer (lower left), 3. total thickness of sand and gravel (upper right), and 4. number of layers (lower right). 


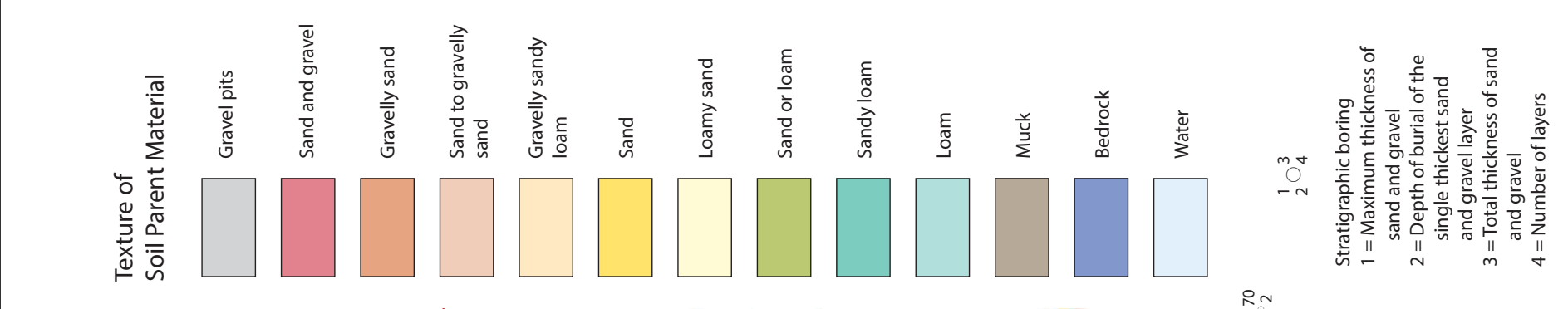

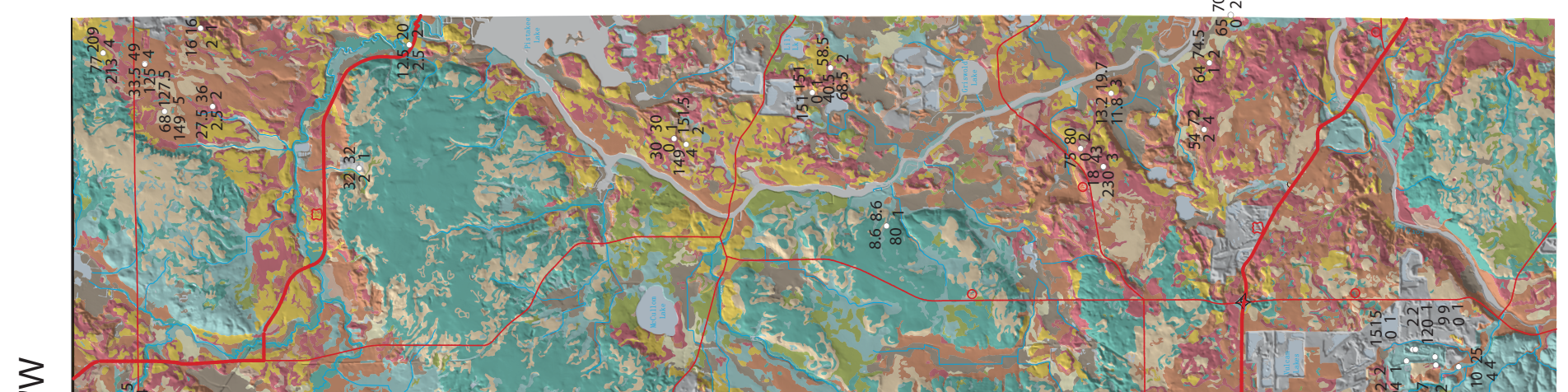

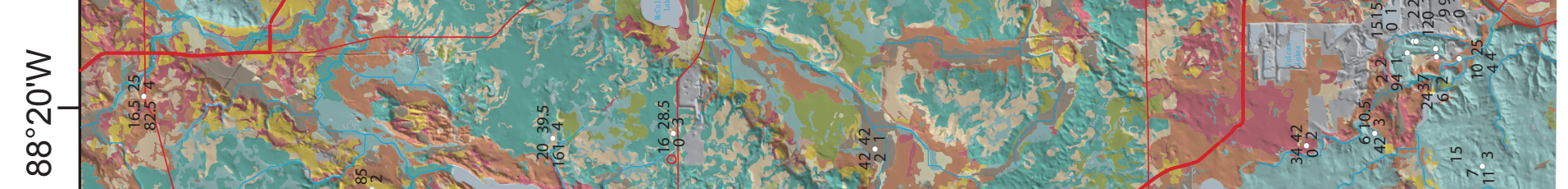
क्ष

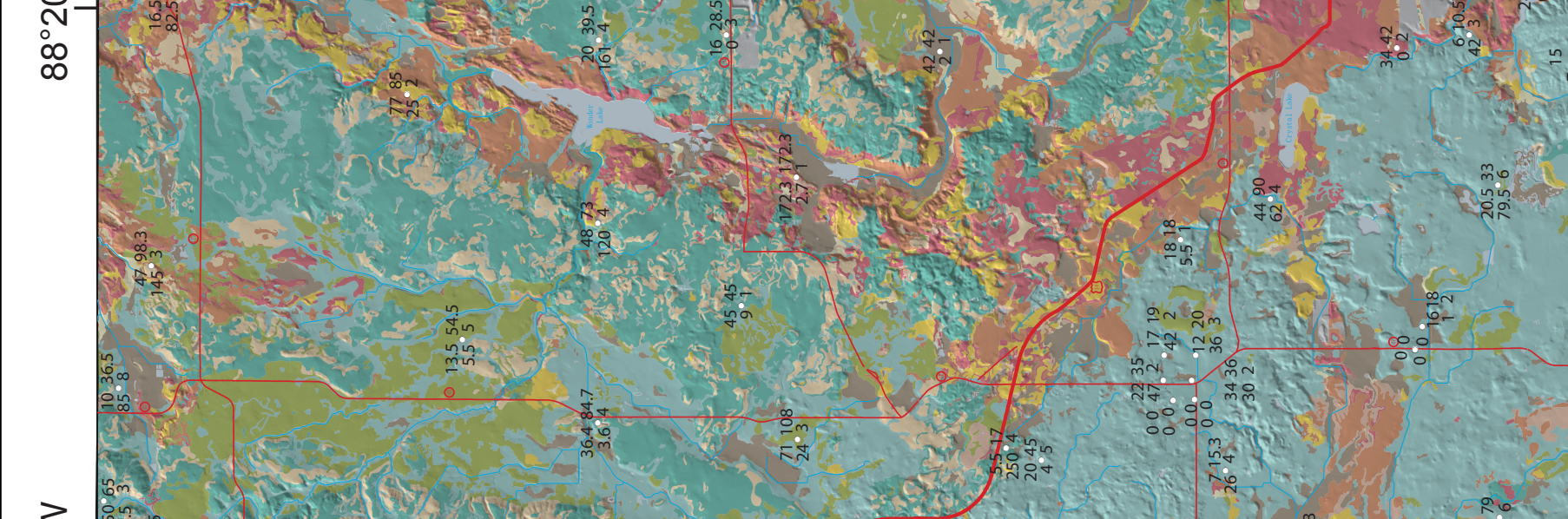

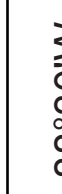

$\begin{array}{lll}3 & 0 \\ 0 & 0 \\ 0 & 0 \\ \infty & 0 \\ \infty & 0\end{array}$

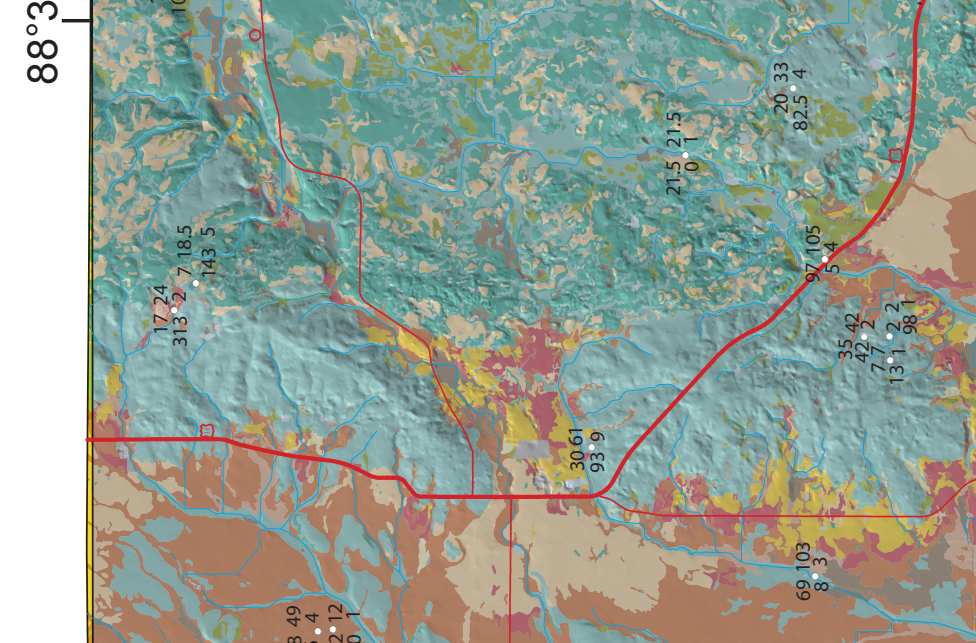

3
3
0
$\vdots$
0
$\infty$
$\infty$
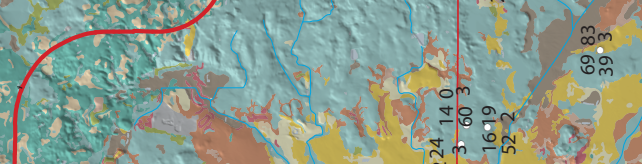